\title{
$\mathrm{Ni}_{60} \mathrm{Mo}_{30} \mathrm{~B}_{10}$ 非晶質粉末をホットプレスした 硼化物分散型複合材料の組織と力学特性
}

\author{
野末 章* 大塚正久** 鈴木啓史* \\ 高山正行**† 田口秀之辢 大久保忠恒* \\ *上智大学機械工学科 \\ **芝浦工業大学金属工学科
}

J. Japan Inst. Metals, Vol. 58, No. 7 (1994), pp. 740-745

\section{Microstructure and Mechanical Properties of Boride-Dispersed Composites Fabricated by Hot-Pressing Amorphous $\mathrm{Ni}_{60} \mathrm{Mo}_{30} \mathrm{~B}_{10}$ Powders}

\author{
Akira Nozue*, Masahisa Otsuka**, Hiroshi Suzuki*, \\ Masayuki Takayama**, Hideyuki Taguchi* and Tadatsune Okubo* \\ *Department of Mechanical Engineering, Sophia University, Tokyo \\ **Department of Metallurgical Engineering, Shibaura Institute of Technology, Tokyo
}

\begin{abstract}
Amorphous $\mathrm{Ni}_{60} \mathrm{Mo}_{30} \mathrm{~B}_{10}$ powders have been hot-pressed, crystallized and heat-treated to control microstructures for excellent mechanical properties.

In materials (HP) hot-pressed at $1373 \mathrm{~K}$, borides such as $\mathrm{Mo}_{2} \mathrm{NiB}_{2}$ are dispersed in $\mathrm{Ni}$ solutions saturated with alloy elements. These boride precipitates are quite fine and homogeneous. Materials of $\mathrm{HP}$ are solution-treated at $1373 \mathrm{~K}$ and aged to precipitate within its Ni solutions (973STA, 1073STA, 1273STA). Symbols of 973, 1073 and 1273 signify aging temperatures. In materials of $973 \mathrm{STA}$ and $1073 \mathrm{STA}$, the borides, and $\mathrm{Ni}_{3} \mathrm{Mo}$ and NiMo compounds are dispersed, but little Ni solution exists. On the other hand, materials of 1273STA are formed of the borides and the NiMo compounds within the Ni solutions.

Materials of 1073STA give higher hardness in the temperature range between 300 and $800 \mathrm{~K}$ compared with $\mathrm{HP}$ materials. Its high hardness is about $8.3 \mathrm{GPa}$ and compressive strength at room temperature is about $3.0 \mathrm{GPa}$. On the other hand, 1273STA materials of relatively high hardness exhibit large ductility because of the existence of the Ni solutions.

It is found that these composites maintain an excellent hardness and a moderate ductility up to about $800 \mathrm{~K}$ due to the thermal stability of its microstructures.
\end{abstract}

(Received December 15, 1993)

Keywords: composite boride, intermetallic compounds, mechanical properties, hot press, amorphous powder, microstructure

\section{I．緒言}

セラミックス，金属間化合物等が次世代の構造用村料として 注目されている。力学特性の優れた材料を開発するには，高い 強度のセラミックスと金属間化合物，ならびに大きな延性と高 い破壊勒珄を有する金属について，それぞれの優れた力学特性 を生かすような複合化が必要である。セラミックスと金属の複 合村料であるサーメットは硬質材料の脆性を改善するために開 発されている．合金元素が非平衡状態で強制的火固溶されてい るアモルファス合金に㨟いて，その粉末の焼結体は力学特性に 優れた合金となる可能性がある(1)-(6)。このバルク結晶化は,

$\uparrow$ 芝浦工業大学大学院生

计 上智大学大学院生
この材料がアモルファス状態を経ているため, 通常の溶解法を たは焼結法で生成された材料とは異なり，多量な元素の均一固 溶, 難烇結体の成形等が可能となる特長を有している。すなお ち，セラミックスと金属間化合物が多量，微細から均一に分散 した高強度な複合材料の製造が期待できる。本研究では，耐熱 合金の基本組成の一つである $\mathrm{Ni}$ ，扣よび硬質酎磨耗材料とし て注目されている研化物系サーメット(7)の基本組成である $\mathrm{Mo}, \mathrm{Ni}, \mathrm{B}$ 学含有与る $\mathrm{Ni}_{60} \mathrm{Mo}_{30} \mathrm{~B}_{10}$ アモルファス粉末合金をホ ットプレスによりバルク結晶化し，熱処理を施すことにより， 矹化物，Ni-Mo 系金属間化合物，Ni 固溶体を分散させた複合 村料を作製しここ林の材料の高温を含めた力学特性について 検討索行う。 


\section{II. 実験 方 法}

\section{1. 供試材}

(1) 原料粉末

モル分率 $\mathrm{Ni}_{60} \mathrm{Mo}_{30} \mathrm{~B}_{10}$ の市販のアモルファスンボン(幅 150 $\mu \mathrm{m}$, 厚さ $20 \sim 60 \mu \mathrm{m})$ から, 粉研機之分級装置を用いて，寸

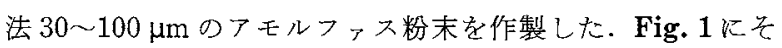
の粉末の外観を示す。

\section{(2) アモルファス粉末の結晶化とバルク成形}

原料粉末を真空中で773から $1073 \mathrm{~K}$ をでの温度で $1.8 \mathrm{ks}$ 間 加熱後, 後述の方法で $\mathrm{X}$ 線回折ピークの確認を行った。過能 和状態の Ni 固溶体を示す明膫な回折ピークの出現し始める温 度を結晶化終了温度とした。

前述の方法で昐末の結晶化終了温度を確認した後, 所定の条 件でホットプレスすることにより, バルク材を得た，关の形状 は長さ $36 \mathrm{~mm}$, 幅 $5 \mathrm{~mm}$, 厚さ $4 \mathrm{~mm}$ で海る. 暁結用の型材 は BN 塗布のカーボンであり，その設計許容応力は約 50 $\mathrm{MPa}$ である。ホットプレス装置内の $1373 \mathrm{~K}$ 亿批ける真空度

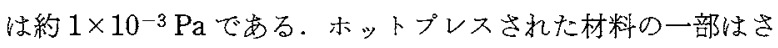
らに，真空中で所定の熱処理が施された。

\section{2. 組織の同定}

(1) 充填率

アルキメデス法(8)火より, バルク結晶材のかさ密度を測定 し, 理論密度との比上り，充填率を求めた。

\section{(2) X 線回折}

グラフォイトモノクロメータ内蔵の島津製作所製 X 線回折 装置XD-D1 使用し，構成相を同定した。回折条件情電圧 $30 \mathrm{kV}$, 電流 $30 \mathrm{~mA}$, 走查速度 $1^{\circ} / \mathrm{min}$ である.

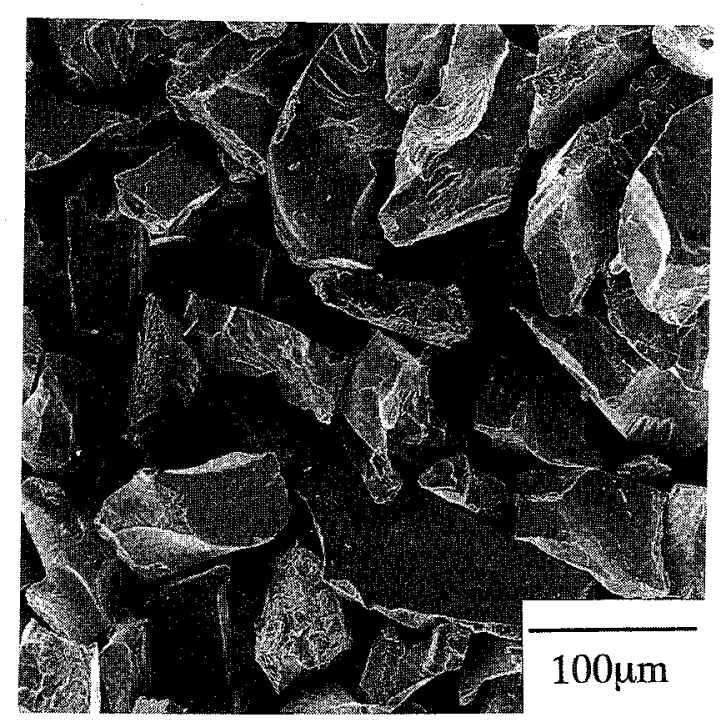

Fig. 1 Scanning electron micrograph of amorphous $\mathrm{Ni}_{60} \mathrm{Mo}_{30} \mathrm{~B}_{10}$ powders.

\section{3. 力学特性の測定}

(1) 硬さ試験

室温硬さについては，ロックウェ儿硬さ計により求め, 高温 硬さ炕ついては，アカシ製のビッカース硬さ計 AVK-HFを用 いて剆定した。この場合，压子の荷重とその保持時間はクリー プ変形が起きない上らに，と机艺れ $9.8 \mathrm{~N}$ と $15 \mathrm{~s}$ とした。試 験片形状は高さ $5 \mathrm{~mm}$, 長さ $8 \mathrm{~mm}$, 幅 $5 \mathrm{~mm}$ の直方体であ り，生子は高さ方向に負荷された。特に高温硬さ試験について は, 試験の正当性を確認するため, 压痕の形状と乞の周辺の梾 子を，走查電子顕徽鏡の反射電子像にて観察した。

\section{(2) 圧縮試験}

寸法 $2.5 \mathrm{~mm} \times 2.5 \mathrm{~mm} \times 6 \mathrm{~mm}$ の試料について,インストロ ン型の万能試駼機仗上り定速圧縮試験を行い，圧縮強さ $\sigma_{\mathrm{B}}$ と 破断委での塑性歪 $\varepsilon_{9}$ を求めた。歪速度は $1.0 \times 10^{-3} \mathrm{~s}^{-1}$ であ る.

\section{III. 結 果}

\section{1. 複合材料の製造}

(1) ホットプレス条件の最適化

本合金のアモルフ、ス紛末を 773 から $1073 \mathrm{~K}$ の温度で 1.8 ks 間加熱後のX 線回折結果を Fig. 2 飞示す. 5 種類のX 線 回折惊，下から非熱処理材，773，873,973,1073 K でとれでれ 保持後のデータである.Fig. 2 に拈いて，下图のアモルフ、ス 粉末では，非晶質を示すハローパターン(9)が現出し，873 Kの 加熱で回折角 $2 \theta か ゙$ 約 $43^{\circ}$ V Ni(111) 面の回折ピークが見られ, 加熱温度の上昇とともに鋭いピークとなり，2 $2 \theta$ が約 $50^{\circ}$ に新た $に \mathrm{Ni}(200)$ 面の回折ピークも観察される.この結果から, 約 $1073 \mathrm{~K}$ て結晶化が浮浜終了していることが理解される.

ホットプレスの条件因子は加圧温度, 加圧量, 加圧時間など で版る。加压温度については, 本アモルフ、ス粉末合金の結晶

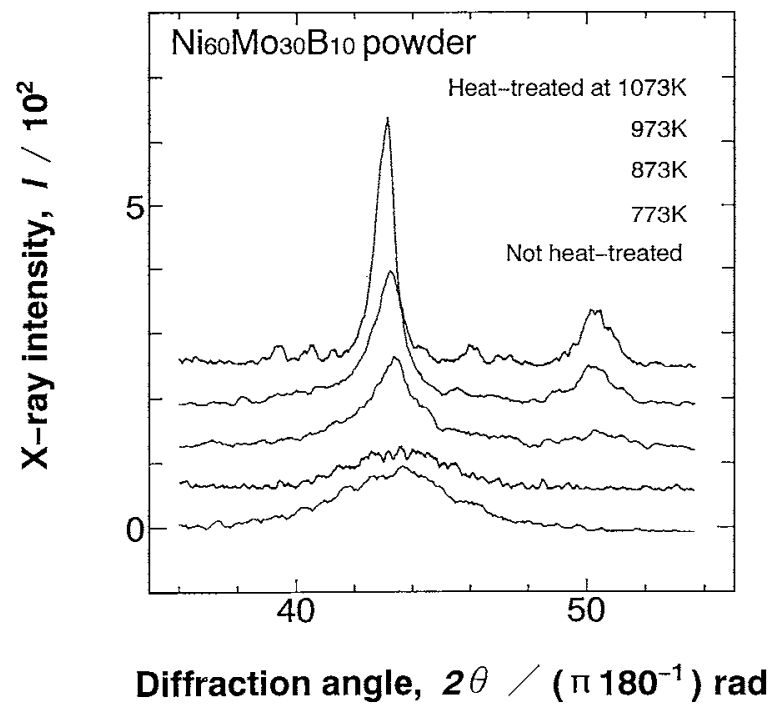

Fig. 2 X-ray diffraction of original amorphous powder samples and those heat-treated at $773,873,973$ and 1073 $\mathrm{K}$ for $1.8 \mathrm{ks}$. 
化終了温度が Fig. 2 より $1073 \mathrm{~K}$ 付近であること，本合金の融 点が約 $1573 \mathrm{~K}$ であることから，この温度範团内で複合材料を 作製し，硬さと充填率を測定した。そ結果をTable 1 亿示 す。な拉，Table 1 飞执いて，加圧量は $40 \mathrm{MPa}$ ，加压時間は $7.2 \mathrm{ks}$ であることから, 硬さと充填率が比較的高く，内部に欠 陥が殆んどなく, 組織の粗大化の少ない加圧温度として, 本研 究では $1373 \mathrm{~K}$ を啇正とした。

加压量については，本研究で使用した焼結用の型材の高温強 度，ならびそ予備実験で行った加圧量と硬さの関係を考虑し， $40 \mathrm{MPa}$ 蒙正とした。

$1373 \mathrm{~K}, 40 \mathrm{MPa}$ の条件でホットプレス装置付属の加圧棒の 変位を時間とともに測定し，Fig. 3 得た。 $1.8 \mathrm{ks}$ 以降，変 位は注ば一定となっている。硬さについて曲，1.8から 10.8 ks の間で汪ぼ一定になっていた。内部欠陥が殆んどなく，硬 さが漂涂一定となり，組織の粗大化が少ないことから，本研究 では $7.2 \mathrm{ks}$ 加圧時間の適正值とした，以下，最適条件 1373 $\mathrm{K}, 40 \mathrm{MPa}, 7.2 \mathrm{ks}$ に执いてホットプレスした焼結合金をHP 材と称する。

Table 1 Hardness and relative density against press temperature.

\begin{tabular}{l|c|c|c|c}
\hline \hline Press temperature, $T / \mathrm{K}$ & 1223 & 1273 & 1323 & 1373 \\
\hline Hardness, $H R C$ & 52.0 & 64.5 & 65.0 & 62.5 \\
\hline Relative density, $R(\%)$ & - & 98.3 & 99.6 & 99.7 \\
\hline
\end{tabular}

Table 2 Hardness for materials of HP, ST, 973STA, 1073STA and 1273STA. HP: as hot-pressed at $1373 \mathrm{~K}$, ST: solution-treated at $1373 \mathrm{~K}$ after hot-pressing, 973STA, 1073STA and 1273STA: aged at 973, 1073 and $1273 \mathrm{~K}$, respectively, after solution treatment.

\begin{tabular}{c|c|c|c|c|c}
\hline Materials & HP & ST & 973STA & 1073 STA & $1273 \mathrm{STA}$ \\
\hline Hardness, HRC & 62.5 & 56.0 & 63.5 & 64.8 & 57.5 \\
\hline
\end{tabular}

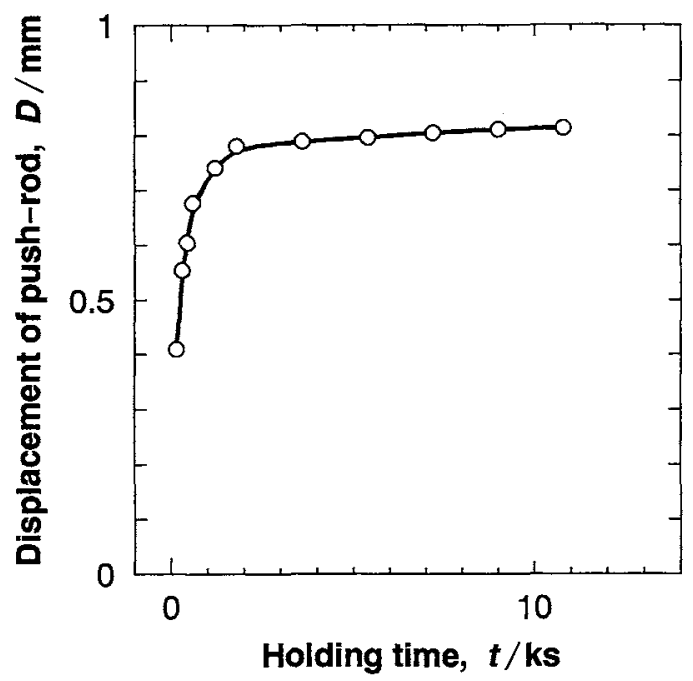

Fig. 3 Displacement of push-rod vs. holding time.
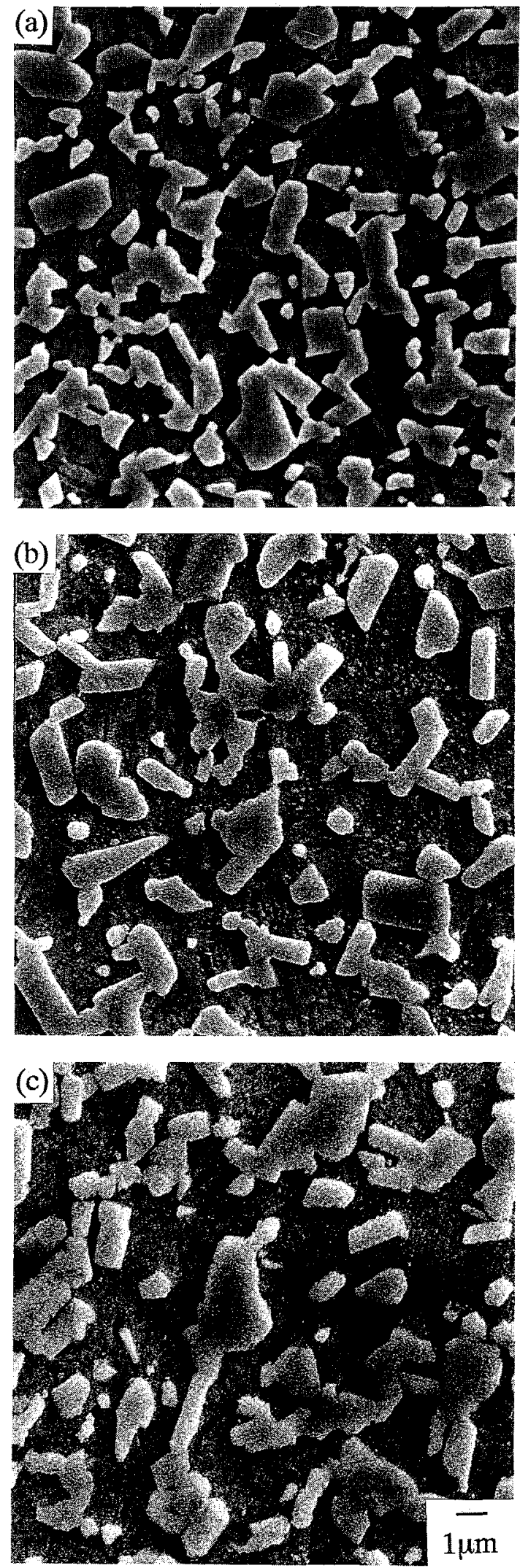

Fig. 4 Microstructures of (a) HP, (b) 1073STA and (c) 1273STA. 


\section{（2） HP 材の溶体化-時効処理}

$\mathrm{HP}$ 材に $1373 \mathrm{~K}, 3.6 \mathrm{ks}$ の溶体化処理を施した後， 3 種類の 温度 $973,1073,1273 \mathrm{~K}$ 飞执いて, 時間 $14.4 \mathrm{ks}$ の時効処理を 行った.これらの熱処理後の冷却方法はいずれも空冷である. 以下，溶体化処理材を ST 材，および $973 ， 1073 ， 1273 \mathrm{~K}$ に拉 ける時効処理材を973STA 材, 1073STA 材, 1273STA 材と それぞれ称する. HP 材, ST 材, 973STA 材, 1073STA 材, 1273STA 材の硬さを Table 2 飞示す. 973STA材と 1073STA 材の室温硬さは HP 材と ST 材と比べ上昇している.

\section{2. 組織の同定}

HP 材, 1073STA 材, 1273STA 材の組織とX線回折の結 果をそれぞれFig. 4(a)〜 (c) と Fig. 5(a)〜 (c) ととれぞれ示 す. Fig. 5(a)〜(c)に拈いて，比較的大きな回折ピークに対応 する物質をピークの上に示している. HP 材と 1273STA 材で は, $\mathrm{Ni}$ 固溶体の大きな回折ピークと, $\mathrm{Mo}_{2} \mathrm{NiB}_{2}$ と $\mathrm{NiMo}$ の回 折ピークが観察されている.ここで, $\mathrm{Mo}_{2} \mathrm{NiB}_{2}$ の第 1 回折ピ ークは約 $43^{\circ}$ に存在し, $\mathrm{Ni}$ 固溶体の第 1 回折ピークのわずかに 左側に位置するが，Fig. 5(a)，(c)では見かけ上，一つの回折 ピークとなっている. 一方, Fig. 5(b)の 1073STA 材では, $\mathrm{Ni}$ 固溶体の回折ピークは殆んど見られず, 新たに $\mathrm{Ni}_{3} \mathrm{Mo}$ の回 折ピークが存在している. $\mathrm{Mo}_{2} \mathrm{NiB}_{2}$ の第 1 回折ピークは $\mathrm{HP}$ 材と $1273 \mathrm{STA}$ 材と同様に約 $43^{\circ}$ そ存在し, $\mathrm{Ni}_{3} \mathrm{Mo}$ の回折ピー クの直ぐ右側に観察されている.

\section{3. 高温硬さと延性}

Fig. 6 亿高温硬さの測定結果を示す. 本研究の試験温度範 囲では, 1073STA 材の硬さは HP 材より高く, 約 $800 \mathrm{~K}$ まで は室温の硬さを維持している. Fig. 6 において, 丸印は測定デ 一タの平均值であり, これらのデータの上限と下限, ならびに $\mathrm{JIS}$ のSKH 相当の M2 と T15 のデータ(4)もあわせて示してい る. HP 材の $973 \mathrm{~K}$ に和ける硬さ試験に沶いて, 生成した圧痕 をFig. 7 亿示す. その形状に乱れはなく, 周囲にき裂の発生 も見られない，各複合材料の室温の圧縮試験より求めた $\sigma_{\mathrm{B}}$ と $\varepsilon_{\mathrm{p}}$ を Table 3 に示す. 1273STA 材は, HP 材と比べ, $\sigma_{\mathrm{B}}$ の大 きな低下はなく, 比較的大きな延性が得られている。

\section{N. 考察}

\section{1. ホットプレスによる製造条件}

複合材料の主な製造条件としては, 加圧温度, 加圧量, 加圧 時間である. 加圧量については, 試験片作製用の型材の強度も 考慮に入れ，可能な限り大きな圧力とした．時間については， Fig. 3 に拈ける変位の変化が殆んどなくなり, 充填率を十分高 くし, 時間はできる限り短く設定した. 本研究では, 複合材料

Table 3 Compressive strength and plastic strain to fracture for HP, ST, 1073STA and 1273STA.

\begin{tabular}{c|c|c|c|c}
\hline \hline Materials & $\mathrm{HP}$ & $\mathrm{ST}$ & $1073 \mathrm{STA}$ & 1273STA \\
\hline Compressive strength, $\sigma_{\mathrm{B}} / \mathrm{GPa}$ & 2.98 & 2.45 & 3.22 & 2.76 \\
\hline Plastic strain to fracture, $\varepsilon_{\mathrm{p}}(\%)$ & 7.60 & 20.2 & 1.30 & 16.3 \\
\hline
\end{tabular}

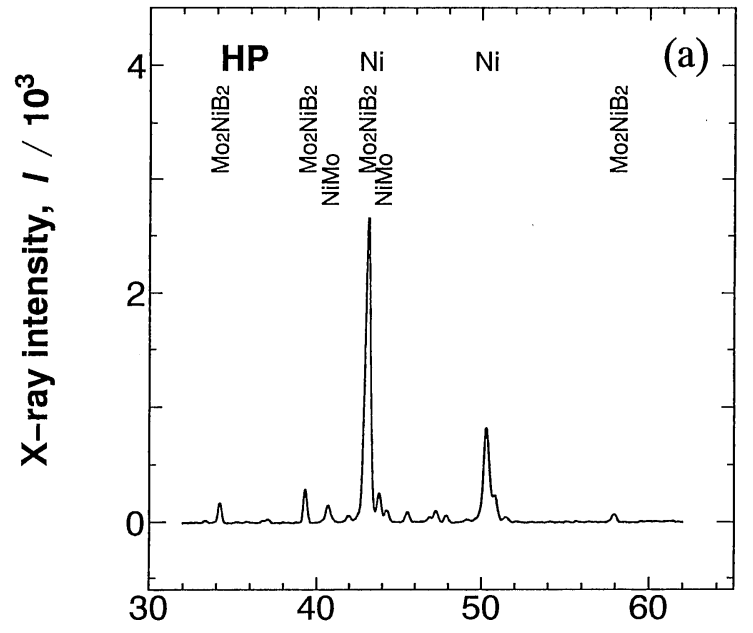

Diffraction angle, $2 \theta /\left(\pi 180^{-1}\right) \mathrm{rad}$

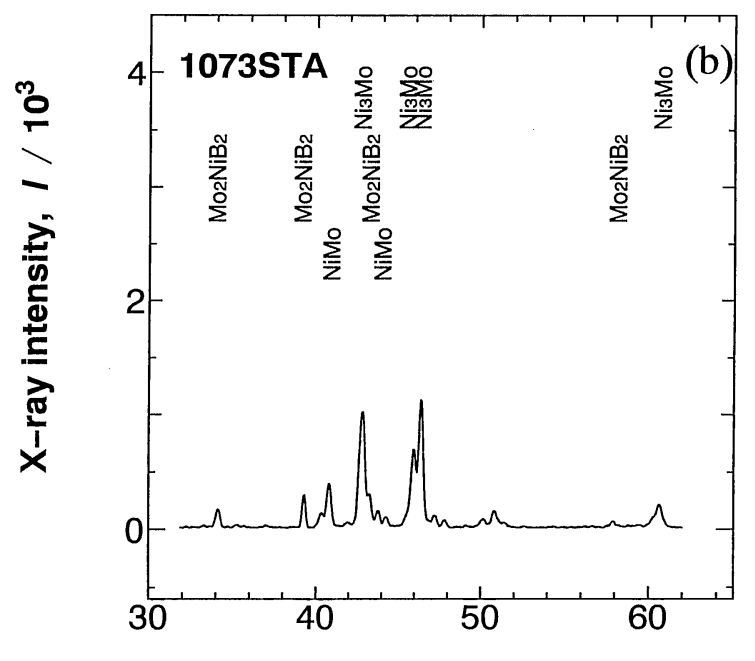

Diffraction angle, $2 \theta /\left(\pi 180^{-1}\right) \mathrm{rad}$

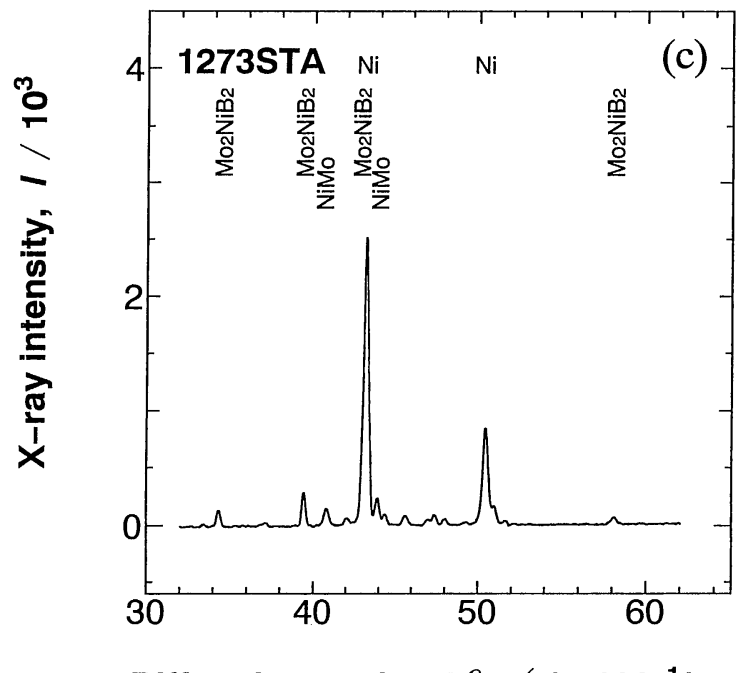

Diffraction angle, $2 \theta /\left(\pi 180^{-1}\right) \mathrm{rad}$

Fig. 5 X-ray diffraction patterns of (a) HP, (b) 1073STA and (c) 1273STA. 


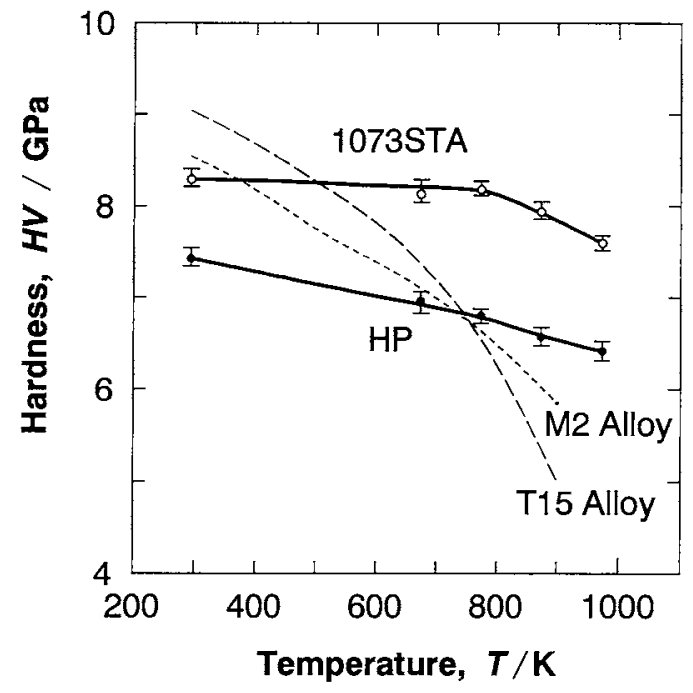

Fig. 6 Hardness as a function of holding temperature for $\mathrm{HP}$ and 1073STA. This figure includes data ${ }^{(4)}$ on $\mathrm{M} 2$ and T15 alloys.

の力学特件に大きな影響を与克る製造条件は加圧温度である。 Table 1 に示されるように, 充填率がでさる限り高くなる温度 として $1373 \mathrm{~K}$ 用いた。この温度では, 加圧中の組織の粗大 化のため，1323 K で加圧した時より室温硬さは低下したが， 充填率は本研究の範囲で最も高くなっている.

\section{2. 複合材料の組織}

焼結前の原料粉末はアモルフ、ス合金であることから，HP 材で存在する $\mathrm{Ni}$ 固溶体は依然過飽和固溶体であると考えられ る. 事実, Fig. 5(a)の Ni 固溶体の回折ピークはASTM カー ドから得られるNi の回折ピーク上り大きく低角側杂れ゙れてい る. Fig. 4(a) 〜 (c) に見方礼る白色の析出物は, Fig. 5(a) (c)のX楾回折の結果から, 主に $\mathrm{Mo}_{2} \mathrm{NiB}_{2}{ }^{(10)}$ である。 $\mathrm{B}$ は $\mathrm{Ni}, \mathrm{Mo}$ の重金属より活性であるから，最初にB系の化合物が 析出したるのと思われる. 時効処理により析出した NiMo, $\mathrm{Ni}_{3} \mathrm{Mo}$ 化合物は母相内に非常に徽細に分散していると考无ら れる．上述の白色の析出物に， $\mathrm{Mo}_{2} \mathrm{NiB}_{2}$ 以外の嗍化物の存在 も考えられる. そこで, 走査電子㩆微鏡に搭載された Link 社 製高速エネルギー分散型 X 線マイクロアナライザーQX2000J を用いて，これらの色の析出物の定量分析を試みた。しかし 照射表面から深さ方向への特性 X 線検出範用(約 $5 \mu \mathrm{m}$ ) が画像 解析に上る析出物の平均䊀径(約 $1 \mu \mathrm{m}$ )を上文わり，析出物の 元素分析が困難なため，正確な同定はできなかった。

このよらな過飽和 $\mathrm{Ni}$ 固溶体を母相とする $\mathrm{HP}$ 材に溶体化-時 効処理在行うことにより，母相中に新たな化合物を析出させる ことが可能である. Ni-Mo二元系状態図(11)-(13)によると, Mo 濃度が $30 \mathrm{~mol} \%$ の時, 約 $1180 \mathrm{~K}$ 亿存在する $\mathrm{Ni} と \mathrm{Ni}_{3} \mathrm{Mo} の$ 变態点より十分に下，または上の温度を時效温度とした．時効 処理による組織の変化としては, 各種硼化物の析出と成長に加 光，新たな析出物として，973STA材と1073STA 材では NiMo と $\mathrm{Ni}_{3} \mathrm{Mo}, 1273 \mathrm{STA}$ 材では NiMo などが考光られる。 Fig. 5(b)，(c)飞和いて，それらの回折ピークがそれぞれ検出

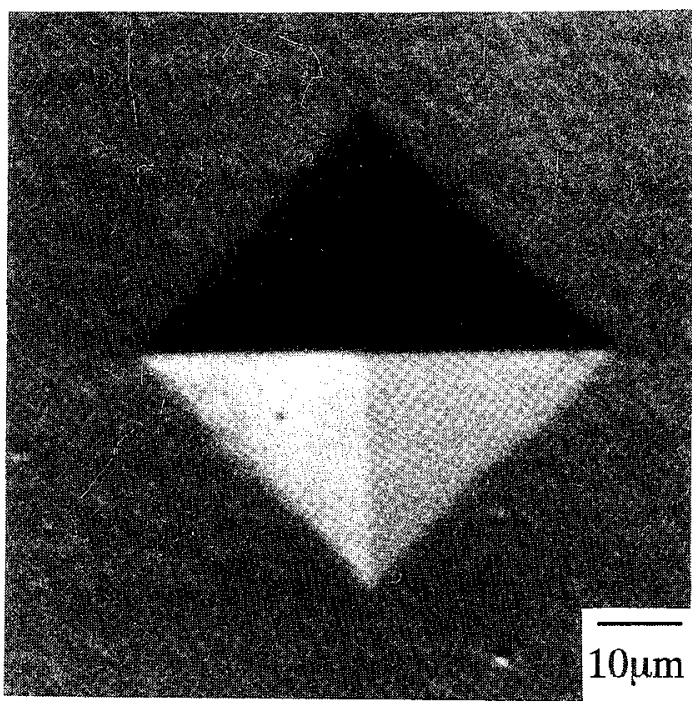

Fig. 7 Morphology of part indented at $973 \mathrm{~K}$ in hardness test for HP materials.

されている。こ扎らの析出物は Fig. 4(a)の HP 材の母相であ った黒色部に主に分布していると考党られる。

\section{3. 複合材料の力学特性}

Table 2 そ执いて, 973STA 材と1073STA 材の硬さが HP 材とST 材の硬さより上昇したのは，HP 材と ST 材の母相よ り析出した $\mathrm{NiMo}, \mathrm{Ni}_{3} \mathrm{Mo}$ 等の金属間化合物によるものと思わ れる. 1273STA 材では 973STA 村と 1073STA 材と比較し, 硬さは低下した。これは母相より NiMoの析出に加六, Ni 固 溶体の体積量が増加したことによるるのと考学られる. Table $3 の \sigma_{\mathrm{B}}$ は Table 2 の硬さと良い相関がある. 延性については， $\mathrm{Ni}$ 固溶体が比較的多く分布していると考えられる 1273STA 材が優れている．本研究では破壊鞄性を測定していないが，延 性の結果加ら 1273STA 材の $\mathrm{K}_{\mathrm{IC}}$ は 973STA 村と 1073STA 材 と比較し，向上していることが推測できる。

本研究で得られるホットプレス成形体は非常に小さく, 引張 試験片の作製が困難なため, 高温での力学特性は高温硬さ試験 より評価した。あわせて高温強度に比較的優れている実用合金 である M2 と T15 と本複合材料の高温硬さの此較も行った。 Fig. 6 に示されるように, 室温硬さはむしろ M2 と T15 が優 れるが，高温硬さは本複合材料の力が優れている．特に，硼化 物と Ni-Mo 系の金属間化合物から主に搆成されていると考兄 られる1073STA 材は, $800 \mathrm{~K}$ 付近まで約 $8.3 \mathrm{GPa}$ と高い硬度 水準を維持している.Fig. 6 K括いてデータの変動が少ないこ と，ならびに Fig. 7 の圧痕の形状に対称性があることなどか ら,クリープ变形は起きて招らず, 高温硬さ試験の結果は信頼 でさるものと思秃机る．Fig. 6 の高温硬さとTable 3 の圧縮強 さの結果から, 1073STA 材の室温 $200 \mathrm{~K}$ の引張強さは 3.0 $\mathrm{GPa}$ 程度と推定される. 


\section{V. 結}

$\mathrm{Ni}_{60} \mathrm{Mo}_{30} \mathrm{~B}_{10}$ アモルファス粉末合金をホットプレスルよりバ ルク結晶化し，さらに各種熱処理を施すことにより，矹化物， Ni-Mo 系金属間化合物，Ni固溶体を均一かつ微細に分散させ た複合材料を作製した，その結果，この複合材料が室温〜800 Kに扎いて高い強度と，める程度の延性を有することが確認 された。

本研究の一部は財池谷科学技術振興財団の研究助成金の補助 を受けたことを付記し，謝意を表します。

\section{文献}

(1) C. C. Wan: Rapidly Solidified Amorphous and Crystalline Alloys, Ed. by B. H. Kear, B. C. Giessen and M. Cohen, North-Holland, (1981), 441.

(2) S. K. Das, K. Okazaki and C. M. Adam: Proc. of TMS/ AIME Conf. on High-Temperature Alloys: Theory and
Design, Ed. by J. O. Stiegler, Bethesda, USA, (1984), 451.

(3) D. Raybound: Metal Powder Report, Allied Corp., USA, 39 (1984), 282

(4) E. J. Vineberg, E. K. Ohriner, E. P. Whelan and G. E. Stapleton: Proc. of TMS/AIME Northeast Regional Meeting on Rapidly Solidified Crystalline Alloys, Morristown, USA, (1985), 1.

(5) S. K. Das and D. Raybould: Rapidly Quenched Metals, Ed. by S. Steeb and H. Warlimont, Elsevier Sci. Pub., USA, (1985), 1787

(6) M. Yoshida, A. Inoue and T. Masumoto: Proceedings of the MRS International Meeting on Advanced Materials, Ed. by M. Doyama et al., Materials Research Society, 3(1988), 489.

(7) 高木研一：鉄と鋼，78(1992), 1422.

（8）立花太郎編：新実験化学講坐 17 , 物質の構造と物性, 丸 善, (1978), 549 .

(9) G. Wei and B. Cantor: Acta. Met., 37(1989), 3409.

(10) Y. W. Kim, L. Rabenberg and D. L. Bourell: J. Mater. Res., 3(1988), 1336.

(11) M. Hansen and K. Anderko: Constitutions of Binary Alloys, McGraw-Hill Book Co., (1958), 968.

(12) C. P. Heijwegen and G. D. Rieck: Z. Metallkde, 64(1973), 150.

(13) T. B. Massalski: Binary Alloy Phase Diagrams, 2nd Edition, ASM, 3(1990), 2637. 